\title{
ボロンフィラメントの引張破断挙 動*
}

森田幹郎**

Mikio Morita : Fracture Processes in Boron Filaments. Brittle filaments with high Young's modulus, such as boron or graphite, are usually broken into pieces when tested under tension. To make clear the fracture mechanism, boron filaments were tensile tested monofilamentally, and the fracture processes were observed photographycally.

The following results were obtained :

(1) The filament fractured first at the weakest point where a relatively large imperfection might exist.

(2) Then, fracture due to the buckling occurred.

(3) Elastic stress wave interference caused the filament to break into pieces.

(Received October 13, 1972)

\section{I. 緒言}

ボロンフィラメントとは、タングステン細線の上に金属 ポロンを化学的に蒸着して作った, 直徍 100〜140ミク口 ンの，高強度，高弾性率を有する䋐維(1)で召張試験をする と，一般の金属緎維と異なり，降伏現象を示ざ゙弾性範井

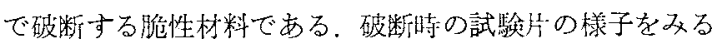
と,カーボン瀻維などと同様に，切れた瞬間に粉々に破础さ れ飛散する。この原因としては，(1) 材料が極めて均質で， 引張試験を行なうと全体が同眭に破壊応力に達するため, 粉々に破断する，(2)どこか此較的大きな欠宿の存在して いた場所で破断したのち，弾性的にもとの長さに復元しよ らとする。その待の衝整的な応力波の干涉により，2 次的

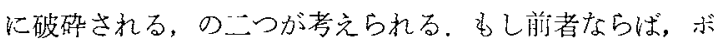
ロンフィラィントがいくら高強度ではあっても，一䇥の応 カに到達した途端に全体がバラバラに壤れることになるの で，安全率をかなり高くとっておかなけ扎ば，位なくて1 次綪造㤃には使えない，西し後者ならば，2次的な応力の 発生を何らかの方法で抑えることも可能なので，補強用緎 維として使光よう。

このような観点からら、ボロンフィラメントの破溯の瞬間 を，写真のフィルム上に固定し，破断挙動を濯べたので， 報告する。

\section{II. 実 験 方 法}

現像がかなり懒いので，高速度映画で連続撮影すること は，できなかった。そこでやむを得ず，Fig.1のように装 置をならべて，破断の瞬間を捕えることにした。すなわち ボロン繊維に微弱な電流を流しておき，これを行って破

** 東京芝浦電気株式会社総合研究所 (Toshiba R \& D Center, Tokyo Shibaura Electric Co., Ltd., Kawasaki)

* 1971年 4 月金属学会東京大会比発表

（1）清水省吾 他：金属材料，9(1969)，No.11，34.
断した僢間に信号を取り出し，切れてから一定時閒経過し たところでストロボスコープを発光させる，䄉維をはさん でストロボと反対側にカメラを固定しておき，発光晆間中 だけフィルムに感光させるといら方法である。この遅延时 開を種タに変化させ，破断後の試験片の举動を調べた。

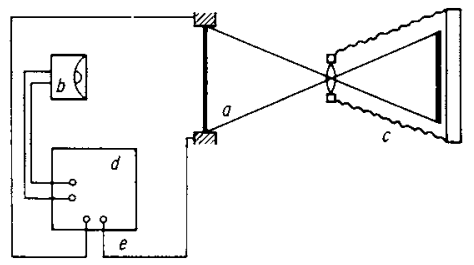

Fig.1 Experimental set-up block diagram $\mathrm{a}$ : specimen, b : stroboscope, $\mathrm{c}$ : camera with Polaloid film, d: power supply, e : breaking signal codes

\section{1. 試験片とその処理}

試料として，東芝製直径 $104 \mu$ のボロン緎維(Lot No.

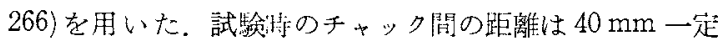

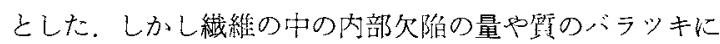
より，強度变動があるので，破断時を予想することが出来 ない，そこで試料に弱い電流を流して扣き，試料が切断し たときに電流が切れることで破断信号を出すことにした。 ボロンは常温では電気抵抗が高いため導電体としては取り 扱えないが，心線にタングステン線を用いているので，こ のW線を信号線とした。線は，ボロン部よりも伸びが大 きいので，タングステン線が外側より先に破断する拉去れ のないことも，一つの利点である。

この目的で，試駗沜のチャック部分をニッケルメッキし て，心線のタングステンと導通を持たせ，このニッケルメ ッキ部をさらにアルミ箈で梜んで端子とした。

\section{2. 試験方法}

引張試駼機は Tensilon UTM- II 型(東洋測器製，口ドセル最大荷重 $5 \mathrm{~kg}$ )を用いた。引掁速度每分 $0.4 \mathrm{~mm}$ (ひ 
ずみ速度每分 $1 \%$ )で試験を行った。

試験機の配置は，先に述へたようにFig.1に示す通りで ある。記録システムとして，大型スチールカメラおよび ASA 3000 のポラロイドフィル人を用いた。照明はストロ

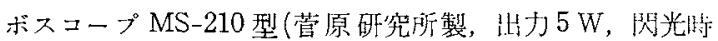
間 $0.8 \mu \mathrm{s}$ 交たは $2 \mu \mathrm{s}$ )である。主として $2 \mu \mathrm{s}$ を用いた。 崌延回路を用いて，フィラメントが切断してから発光する

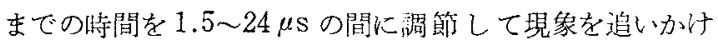
た。荤延時間 DT は破断してから，ストロボが発光し最人 輝度の半分に到達するまでの時間で表わした。

\section{III. 実 験 結 果}

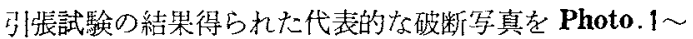
Photo.6亿示寸，写真説明文中 DT は掘延時閒，uts 破 断強度を示す。測起の方式上，一つの試料では 1 枚の字真 しか撮影されなかったので，㦑密な意味では同一織維の破 断後の学動とはいい難いが，大体の傾问はつかめょう。

Photo.1は，破断 $2 \mu$ s 後の写真である。この佶点では破 断は添淁中央の1カ所でしか切れていない，やはりどこか 最も弱い場所から破断することが，明らかにされた。線に 振動が生じたためか，穾祭のものより太如写っている。

Photo. 2 は破断 $7 \mu \mathrm{s}$ 後の写真である。(a) では試料の中
央よりやや下のオで切れたのち，残った線の長いちのチャ ック部で挫唇に上り切れ，(b)では逆に短い力のチ+ック 部で2次的に切断している。したがってチ+ック部で切れ るのに試料長さの半分以上のものの婵動エネルギーがない と切れないといらことはなく，比較的小さなエネルギーで 挫暨しそらである。全体に波動が生じている．Photo.3で はこの壯間ではチャック部での挫属は認められない，試験 終了後には全部の試料が破断しチャック部には何も残って いない。

さらに街間が経過すると，Photo.4にみられるよ5に， 最初の大きく屈曲した部分の中がさらに細分化され，粉末 となって飛散する。これはボロンのみが粉本になるある いはWとボロンの㔀離が生じるといらのではなく，ボロン 部とタングステン部は密着したまま長手方向に細分化され る。この細分化の程度は，強度の高いものすなわち，破断 に到るまでに貯えられるひずみエネルギ一の大きなものほ ど大きい.Photo. 5 に中程度の強度を示す試料，Photo. 6 は低応力で破断したものを示すが，この場合はかなり長い ままで武料が残る。逆にいらとチャック部に㙛るのは何ら

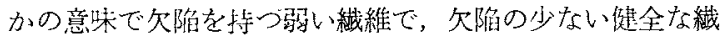
維は試駼後,チャックには何も残らない。

試賖片の破断の順序を模型的に示すと，Fig.2が得ら

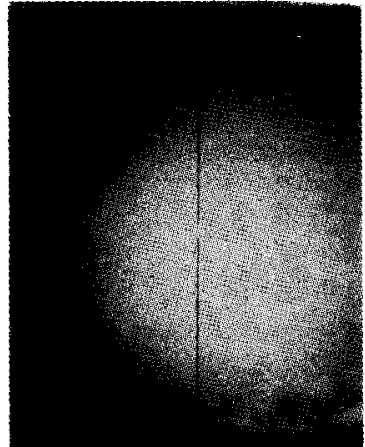

Photo.1 Fracture behavior of a boron filament at $2 \mu \mathrm{s}$ (uts $=387.9$ $\mathrm{kg} / \mathrm{mm}^{2}$ )

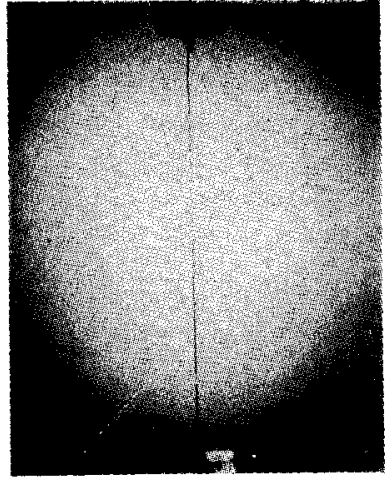

Photo.3 Fracture behavior of a boron filament at $7 \mu \mathrm{s}$ (uts $=390.2 \mathrm{~kg} / \mathrm{mm}^{2}$ )
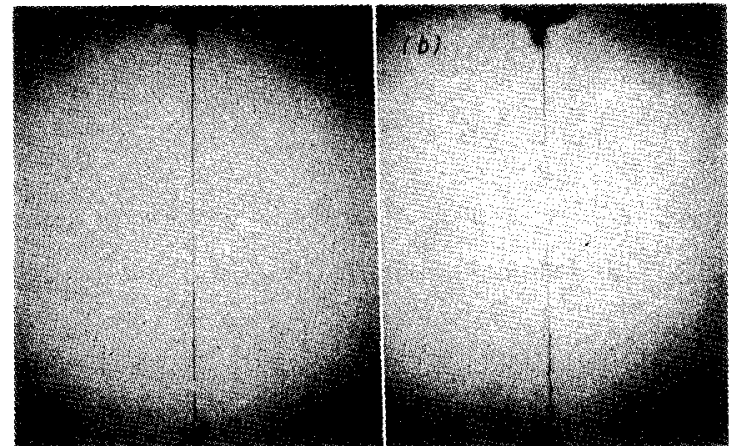

Photo.2 Fracture behavior of boron filament, (a): at $7 \mu \mathrm{s}$ (uts $=352.7 \mathrm{~kg} / \mathrm{mm}^{2}$ ), (b) : at $8 \mu \mathrm{s}$ (uts $=392.1 \mathrm{~kg} / \mathrm{mm}^{2}$ )

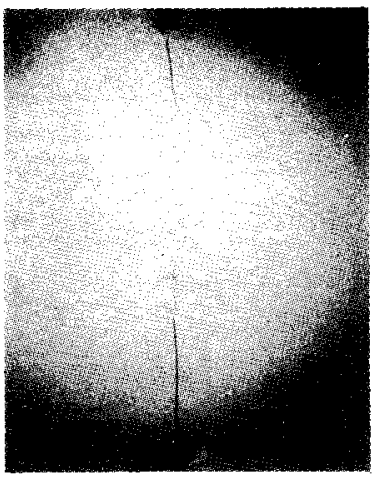

Photo.4 Fracture behavior of a boron filament at $15 \mu \mathrm{s}$ (uts $=422.7 \mathrm{~kg} / \mathrm{m}^{2}$ )

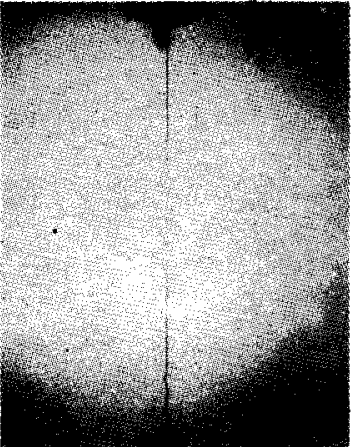

Photo.5 Fracture behavior of a boron filament at $14 \mu \mathrm{s}$ (uts $=323.8 \mathrm{~kg} / \mathrm{mm}^{2}$ ) 


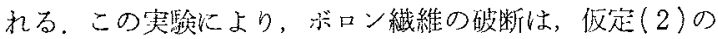
よらにどこか1 カ釷で切れ，その後 2 次的に粉々になるこ とが眀らかになった。

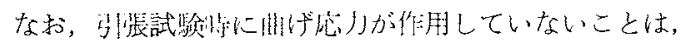

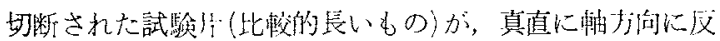
対側のチャックに集きささることにより确陉された。

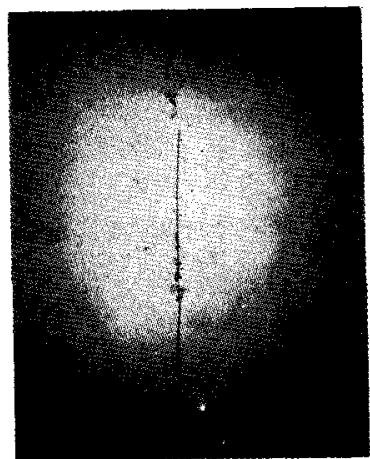

Photo. 6 Fracture behavior of a boron filament at $23 \mu \mathrm{s}$ (uts $=232.9 \mathrm{~kg} / \mathrm{mm}^{2}$ )
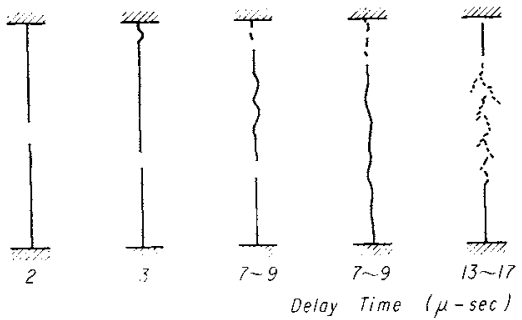

Fig.2 Fracture processes in a boron filament

破断面の SEM 突真の例を Photo.7〜Photo.9に示す。 Photo.7は，低強度の織維で，ボロンとタングステン線の 界面から，クラックが発生しているよらである。この界面 には, $W_{2} \mathrm{~B}_{5}, W_{4}$ のよらなボライドの生成している可能 性が高い，Photo.8は程度の強度を示した㵶維の断面で ある. Photo.9は，高強度を示したものできれいな一つ

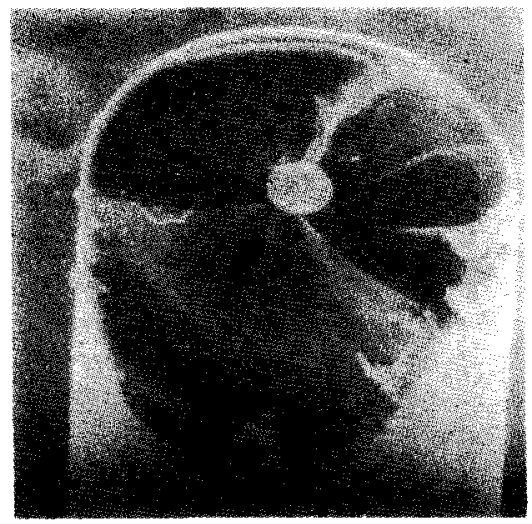

Photo.7 SEM micrograph of the fractured part in a boron filament under a relatively low ultimate tensile strength $(\times 1000 \times 3 / 5)$

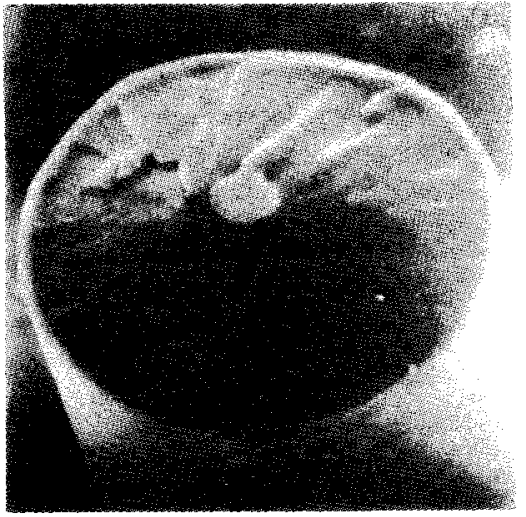

Photo. 8 SEM micrograph of a boron filament section under a medium tensile strength $(\times 1000 \times 3 / 5)$

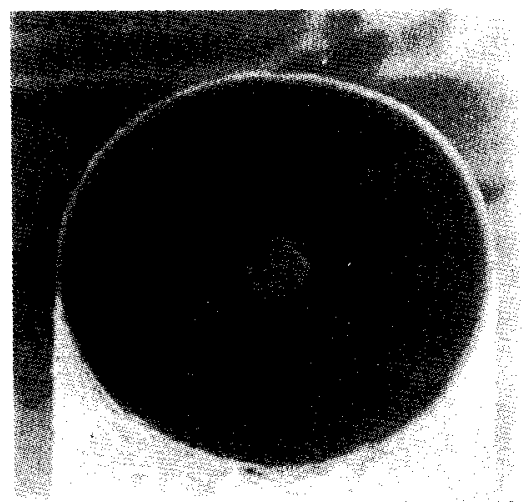

Photo.9 SEM micrograph of a boron filament section under a high tensile strength $(\times 1000 \times 3 / 5)$

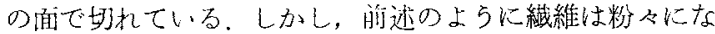
るので、これら Photo.8，9がクラックの最初に発生した 面の写真といら詇ではなく，試駺後拾い集めた試料の中 にここょらな破面を星するものが多かったことを意味し ているに過ざない，WとBの率離した写真は得られなかっ たのでこの間の結命はかなり強いものと䎊められる。

\section{IV. 考察}

フィラメントが，比较的大さな欠陷のある筒所すなわり

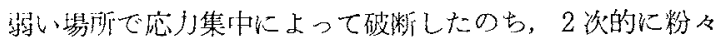
に破断する機構として次のよらなことが考えられる。

\section{1. チャック部での挫屈}

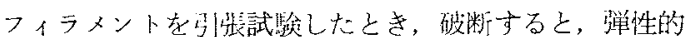

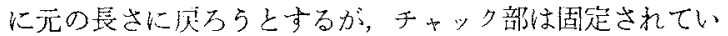

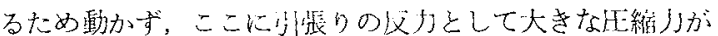
かかかり、フィラメントが挫厥する。これはボロンに限ら

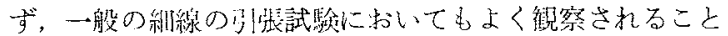

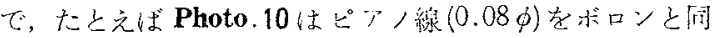
じような条件，すなわらひず文速度每分 $1 \%$ で試験したの 


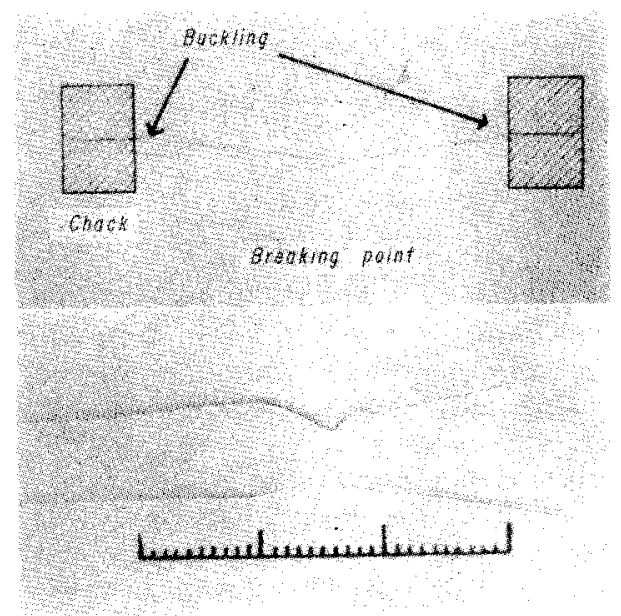

Photo.10 Fracture behavior of a piano wire

らの写真であるが，明らかにチャック部で挫屈を起す。た だしヒノノ線は塑性変形能が大きいので，チャック部での 破壇には到っていない。

一端支持の場全，Euler 挫屈の起こる条件は(2)

$$
P_{\mathrm{cr}}=\pi^{2} E I / 4 l^{2}
$$

とされている，Eは弾性率，lは棒の言さである。. 円形断 面の場会，直径をdとすれば

$$
I=\pi d^{4} / 64
$$

であるため

$$
\sigma_{\mathrm{cr}}=4 P_{\mathrm{cr}} / \pi d^{2}=\frac{1}{64} \cdot \pi^{2} \cdot E \cdot\left(\begin{array}{c}
d \\
l
\end{array}\right)^{2}
$$

$E=42000 \mathrm{~kg} / \mathrm{mm}^{2}$ ，中央で戓れたとして $l=20 \mathrm{~mm} ｄ=$ $0.1 \mathrm{~mm}$ とすると

$$
\sigma_{\mathrm{cr}}=0.16 \mathrm{~kg} / \mathrm{mm}^{2}
$$

といらきわめて小さなナで挫䘑することになる。切れた瞬 間にどの程度の反おがチャック部に生じるかわからない

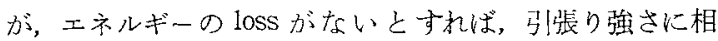

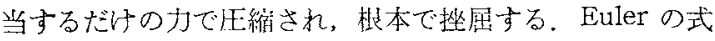
をと炕㞔し

$$
P_{\mathrm{cr}}=(2 n+1)^{2} \cdot \pi^{2} E I / 4 l^{2}
$$

ただし $n$ は 0 を含虰任意の整数(周期)とし $\sigma=400 \mathrm{~kg} /$ $\mathrm{mm}^{2}$ とすると $n \fallingdotseq 24$ ときわわて多数回の曲がりを生じる ことになる、すなわち $0.4 \mathrm{~mm}$ ぐらいの長さで全面に期が り破壊する可能性长示宁。

実娩では Photo.2 (b)などではっきり示さ机ているよら に $n=2$ 程度切れているので，チャック部での消賃される ガはかり小さい $\left(n=2\right.$ として $\left.\sigma=4.1 \mathrm{~kg} / \mathrm{mm}^{2}\right)$.

（2）他威雄 他訳：チモシェンコ，挫屈理論，コロナ社， (1953)

\section{2. 繊維中央での挫届}

チャック部で切れる，あるいは応小波がチャック部で区 射されると，逆何きの招が働く，取初の切断点近傍からの

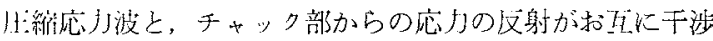

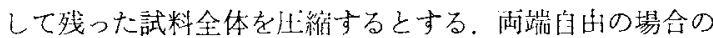

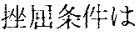

$$
P_{\mathrm{cr}}=\pi^{2} E I / l^{2}
$$

となり，式(1)より 4 倍大きいが，1 $\mathrm{kg} / \mathrm{mm}^{2}$ 以下の席力 で挫局することになる。

このようにいろいろな原因が重なりフィラメントは細断 される，正確なことはわからないが，次の順序で妃断して いる．(1)中矢近傍で切断，(2)千ャック部近傍の䋞維の弾性

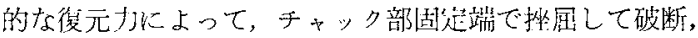
(3)チャック部での破断によって逆向きの応力波の発生，あ

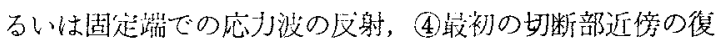
元による応才没と，チャック側からの反射波の干涉，(5)残 った試験片の中央近傍が挫螌破壞する。

しかし，可归試験すると粉々に填れるのが本質的なるの ではなく，2次的なものであり，しかも主因が端部での挫

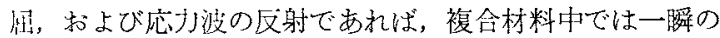
らちに寸断されるようなことは起らないので，安心して使 用できる。というのは、マトリックス中では挫屈のおそれ が少ない上これによって広才波を吸取できるからである。

\section{V. 結 論}

ボロソフィラメントを引張試験し，破断の様柏を調ベた 結果次のことが判明した。すなわら, 壮ロンフィラメント はバラハシラに引きちぎられるよ5に見竞るが，破偯の順序 は，

（1）此較的弱い1力哳で破断する。

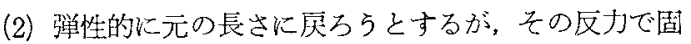
定端で挫愿する。

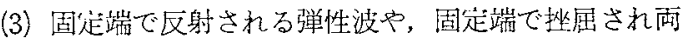
嵓フリーになった線間の応力波の干啮によって，残った試

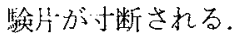

したがって，複合材料にした場合にはこの現象は無視で き，全体が一度に破壊することは根らないと考方られる。

写真撮影にあたっては，株式会社ナックの牛窪 正, 丸山

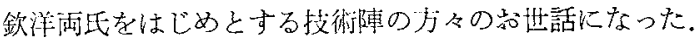

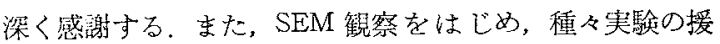
助をいただいた，東芝総研，横山時雄氏，竹田博光両氏， また検諳に加わっていただいた同武井明朗氏に謝意を表し 交す。 